Brit. J. industr. Med., 1965, 22, 172.

\title{
EFFECTS OF CALCIUM SODIUM ETHYLENEDIAMINETETRA - ACETATE ON THE KINETICS OF DISTRIBUTION AND EXCRETION OF LEAD IN THE RAT
}

\author{
BY \\ N. CASTELLINO and S. ALOJ \\ From the Institute of Industrial Medicine of the University and \\ the Institute of General Pathology of the University, Naples
}

(RECEIVED FOR PUBLICATION MARCH 19, 1965)

The effects of calcium sodium ethylenediaminetetra-acetate $\left(\mathrm{CaNa}{ }_{2} \mathrm{EDTA}\right)$ on the kinetics of distribution and excretion of lead $\left({ }^{210} \mathrm{~Pb}\right)$ have been studied in rats. When the chelant was given intravenously, at $50 \mathrm{mg}$./rat daily after a single intravenous injection of $100 \mu \mathrm{g}$. lead/rat, it greatly increased the urinary excretion of lead but reduced the faecal excretion. The greatest effects occurred in the rats treated with chelant shortly after the lead injection. When the chelant was given seven or more days after the lead the increase in lead excretion was negligible. $\mathrm{CaNa}_{2}$ EDTA mobilized lead from every tissue, but the kinetic analysis of the disappearance of ${ }^{210} \mathrm{~Pb}$ showed the presence of two elimination phases. Lead ions weakly bound to the cells were rapidly removed by EDTA, whereas the lead fixed to endocellular constituents was only slowly removed. The chelant did not mobilize lead from bone.

Probably $\mathrm{CaNa}_{2}$ EDTA entered the extravascular space but not the cells. Hence it only accelerated the passage of lead from the cells by lowering the concentration of lead outside them.

${ }^{210} \mathrm{~Pb}$ was also given orally in doses of $500 \mu \mathrm{g}$. lead/rat. About $18 \%$ of the dose was absorbed through the intestine to be distributed in all tissues. Rats treated orally with $\mathrm{CaNa}_{2}$ EDTA showed an increase in urinary lead excretion and a reduction in lead fixed in the body.

Ethylenediaminetetra-acetic acid (EDTA) is widely used in the prevention and treatment of lead poisoning for its property of binding $\mathrm{Pb}^{++}$ions and so forming a relatively stable and non-toxic complex. Since EDTA may form complexes with other ions, in practice the drug is given as its calcium chelate $\left(\mathrm{CaNa}_{2} \mathrm{EDTA}\right)$ to prevent loss of calcium from the body.

The EDTA has been given by different routes: intravenous, oral, and aerosol inhalation (Kehoe, 1955; Zambrano and Rossi, 1955; Teisinger and Srbová, 1956; Bell, Gilliland, Boland and Sullivan, 1956; Bastenier, Deslypere, and de Graef-Millet, 1958; Desoille, Albahary, Truhaut, and Boudène, 1958; Petrović, Stanković, Savićević, and Poleti, 1960; Albahary, Truhaut, Boudène, and Desoille, 1961; Williams, Matthews, and Judd, 1962; Castellino and Grieco, 1964). The work of these authors, among others, shows that lead excretion is increased after EDTA administration, but where and how rapidly lead is mobilized is not satisfactorily known.

The metabolism of EDTA labelled with ${ }^{14} \mathrm{C}$ has been studied in rats and in man by Foreman, Vier, and Magee (1953) and by Foreman and Trujillo (1954). After parenteral injection, $\mathrm{Ca}^{14} \mathrm{C}$-EDTA spreads rapidly from the vascular system and is not concentrated in any tissue. The compound is rapidly and totally excreted through the kidneys, and after six hours $95 \%$ to $98 \%$ of the dose is found in the urine. The compound is poorly absorbed by the gastro-intestinal tract (in the rat a maximum of $18 \%$; in man a maximum of $5 \%$ ) and not at all through the skin. The low intestinal absorption of $\mathrm{CaNa}_{2} \mathrm{EDTA}$ has been confirmed by Srbová and Teisinger (1957), who found only $16.6 \%$ and $2.6 \%$ was absorbed in the rat and in man respectively.

Teisinger, Lustinec, and Srbová (1958a) studied the effects of $\mathrm{CaNa}_{2}$ EDTA by liver perfusion in a normal and a poisoned cat, and Teisinger, Zumanová, and Zezula (1958b) studied the effects by 
the dialysis of blood samples containing lead, using different concentrations of the chelant. Lead is bound reversibly in cells, and the author concluded that the slow process of lead transfer is probably related to the equilibrium of the metal between cells and extracellular fluids. EDTA can speed up this process several times, probably by disturbing the equilibrium, i.e., the $\mathrm{CaNa}_{2}$ EDTA rapidly carries away lead ions that are released from the tissue but does not penetrate into the cells.

Our previous work on the kinetics of distribution and excretion of ${ }^{210} \mathrm{~Pb}$ shows that the removal of lead from different tissues occurs at different rates and also that from every tissue except bone there are one or two phases of rapid removal followed by a slow final phase (Castellino and Aloj, 1964). We suggested that the initial rapid phases correspond to the removal of free or weakly bound ions from the extracellular spaces or from the cells, whereas the slow final phase may represent the removal of lead firmly bound in the cells, perhaps as an organic complex.

The aim of this paper is to examine the rates of $\mathrm{CaNa}_{2} \mathrm{EDTA}_{\mathrm{A}}$ action, and to verify the above hypothesis on lead metabolism. The $\mathrm{CaNa}_{2}$ EDTA has been administered at different time-intervals from ${ }^{210} \mathrm{~Pb}$ injection corresponding to the various removal phases.

\section{Methods}

Animals.-Forty male Wistar rats .weighing between 180 and $210 \mathrm{~g}$. were used.

Tracer Compound.-The ${ }^{210} \mathrm{~Pb}$ acetate was supplied by the Radiochemical Centre, Amersham, Great Britain, with a specific activity of $50 \mathrm{mc} / \mathrm{millimol}$. For injection this was diluted with $0.0001 \mathrm{~N}$ acetic acid. Activity determinations were carried out employing a well type crystal scintillation counter* by estimating the $\gamma$-emission of ${ }^{210} \mathrm{~Pb}$. This is a weak radiation $(0.047 \mathrm{MeV})$ and efficiencies were about $2 \%$.

\section{Treatment of Rats}

Intravenous Injection of Lead Acetate followed by Intravenous Administration of $\mathrm{CaNa}_{2} E D T A$.- Six groups of five rats each were injected via the femoral vein with $0.2 \mathrm{ml}$. of lead acetate solution, $p \mathrm{H} 4 \cdot 7$, containing $100 \mu \mathrm{g}$. lead/rat.

Five of these groups were given $\mathrm{CaNa}_{2} \mathrm{EDTA}$ intravenously 24 hours after the lead and every 24 hours thereafter until the animals were killed at 3, 6, 8, 10, and 12 days.

In the sixth group treatment with $\mathrm{CaNa}_{2}$ EDTA was started seven days after the lead injection and was repeated in three cycles of three daily injections each until the animals were killed on the twenty-third day.

*Nuclear, Chicago.
Oral Administration of Lead Acetate and $\mathrm{CaNa}_{2}$ EDTA. -In two groups of five rats each, $500 \mu \mathrm{g}$. lead/rat was given. The rats were killed 24 hours later. The first group of rats was treated a few days before and during the experiment with $\mathrm{CaNa}_{2} \mathrm{EDTA}$ administered ad libitum as a $1 \%$ solution in the drinking water. The second group was not treated with chelant and was kept as a control.

Sampling.-During the experiments all the rats were kept in individual metabolism cages for separate collection of urine and faeces. Faeces and urine were collected, and the faeces were dried for 24 hours at $100^{\circ} \mathrm{C}$. and then pulverized. The rats were killed by blood-letting. Blood was taken by heart puncture with a heparinized syringe. A portion was centrifuged and separated into plasmatic and cellular components.

The following tissues were obtained at necropsy: striated muscle, liver, kidneys, lungs, spleen, heart, and femur.

In the animals treated orally with lead the whole gastrointestinal tract was taken and hydrolysed in hot $\mathrm{NaOH}$ ( $33 \%$ by wt.).

The analytical methods and the kinetic analysis were as given in our previous paper (Castellino and Aloj, 1964).

\section{Results}

Intravenous Injection of Lead Acetate followed by Intravenous Administrations of $\mathrm{CaNa}_{2}$ EDTA

Treatment with $\mathrm{CaNa}_{2}$ EDTA Starting 24 hours after Lead.-Table 1 gives the ${ }^{210} \mathrm{~Pb}$ concentrations/g. of fresh tissue and their variation with time. The highest values were found in the bone, renal and hepatic tissues and, in decreasing order, in the splenic, pulmonary, cardiac, and striated muscle tissues.

In the blood, lead was mainly bound to the cells and more than $10 \%$ was found in the plasma only at the beginning of the treatment with chelant. These initial high plasma concentrations resulted from the massive removal of lead ions from the tissue into the plasma when $\mathrm{CaNa}_{2}$ EDTA was first administered.

The total lead contents of whole organs were calculated, and the kinetics of ${ }^{210} \mathrm{~Pb}$ disappearance are shown in Figures 1 to 6 . In these figures the experimental points corresponding to 1,12 , and 24 hours are taken from the previous paper on control rats (Castellino and Aloj, 1964).

For all the tissues that have been examined, the concentrations of ${ }^{210} \mathrm{~Pb}$ remaining in them could be expressed by a sum of only two exponential terms, i.e., in the treated rats the two initial phases of ${ }^{210} \mathrm{~Pb}$ removal observed in controls were blended into one with a biological half life of eight to 12 hours. In both controls and treated animals a slow final phase followed. Disappearance at this stage was rather faster in the treated rats (half life 53 to 216 hours) than in the controls (half life 192 to 610 hours). Thus 


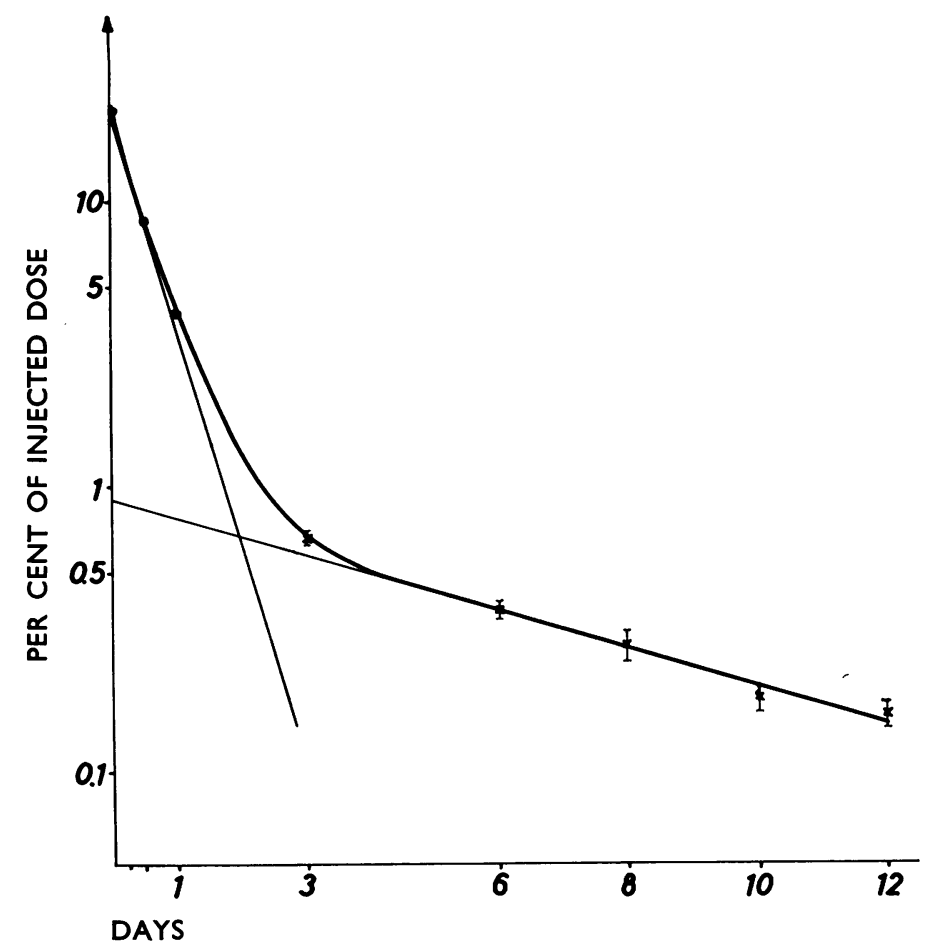

FIGs. 1 to 6.-Variation with time of total ${ }^{210} \mathrm{~Pb}$ in blood and various tissues. 


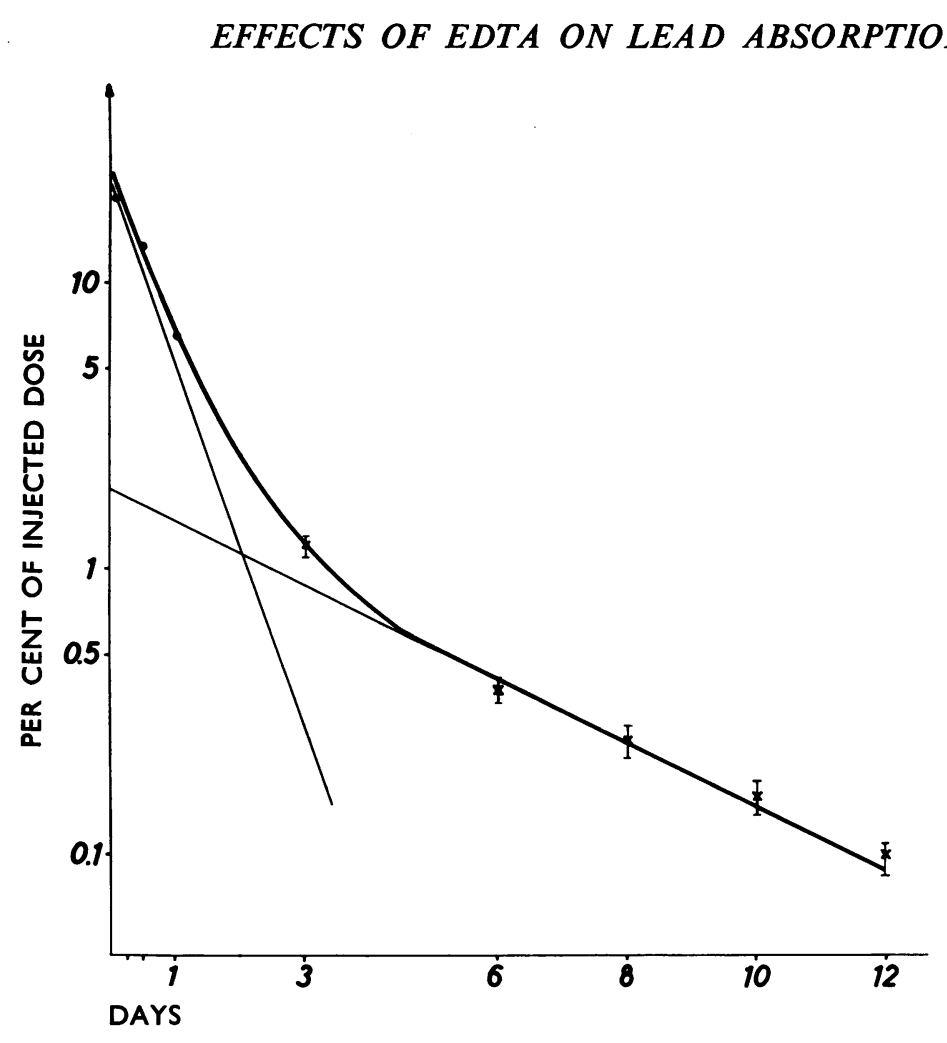
FIG. 3.-Liver: Per cent $=19 \cdot 2 \mathrm{e}^{-0 \cdot 088 t}$
$+2 \cdot 35 \mathrm{e}^{-0.013 t}$

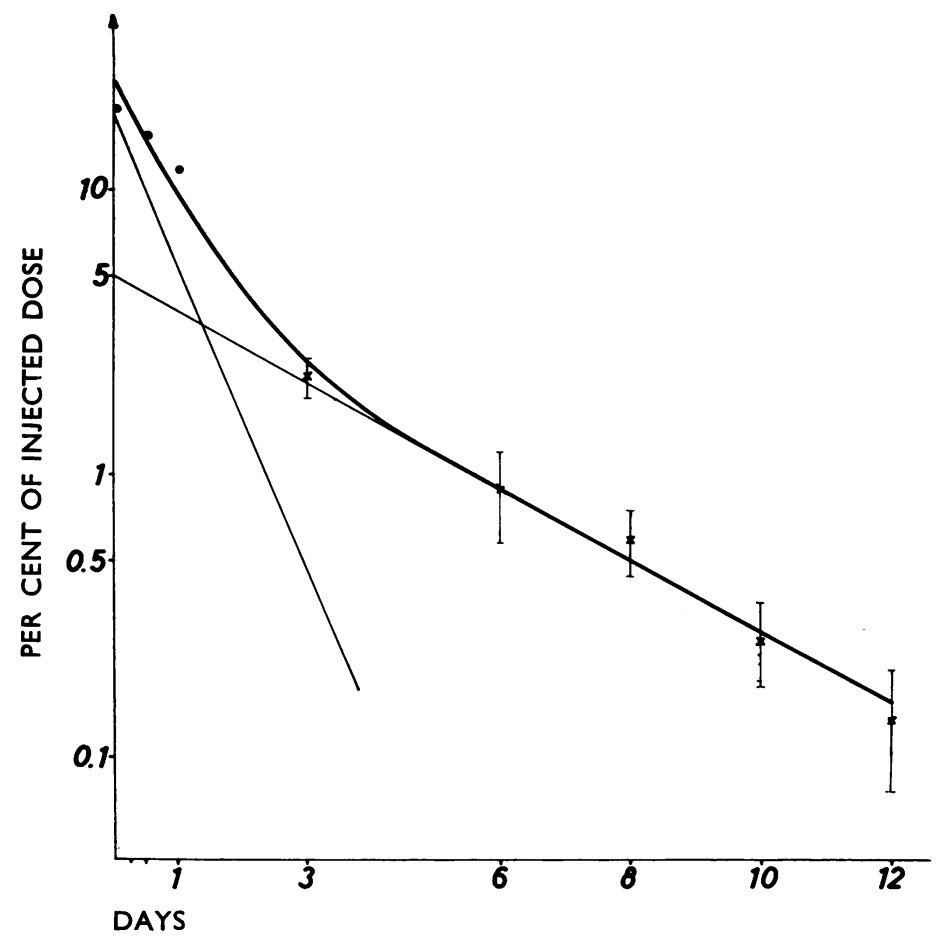
$\begin{aligned} \text { Fig. 4.-Kidney: Per cent }=16 \cdot 7 \mathrm{e}^{-0.058 t} & +5 \cdot 0 \mathrm{e}^{-0 \cdot 012 \mathrm{t}}\end{aligned}$ 


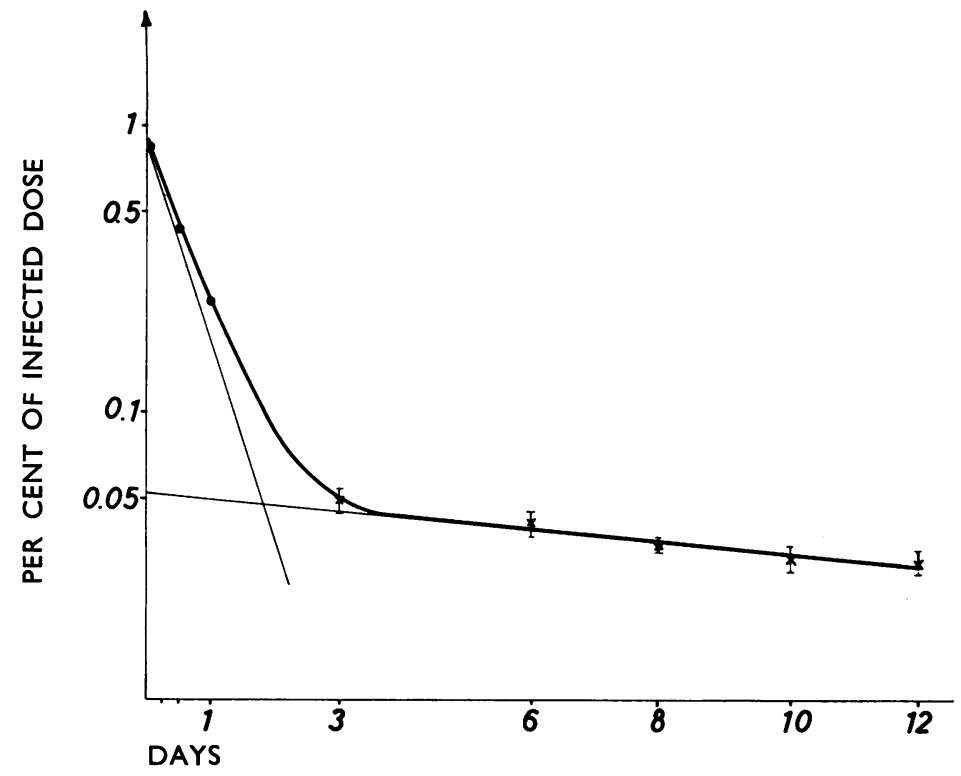

Fig. 5.- Lung: Per cent $=0.877 \mathrm{e}^{-0.088 t}$

FIG. 6.-Heart: Per cent $=0 \cdot 133 \mathrm{e}^{-0.082 t}$ $+0.0063 \mathrm{e}^{-0.0072 t}$

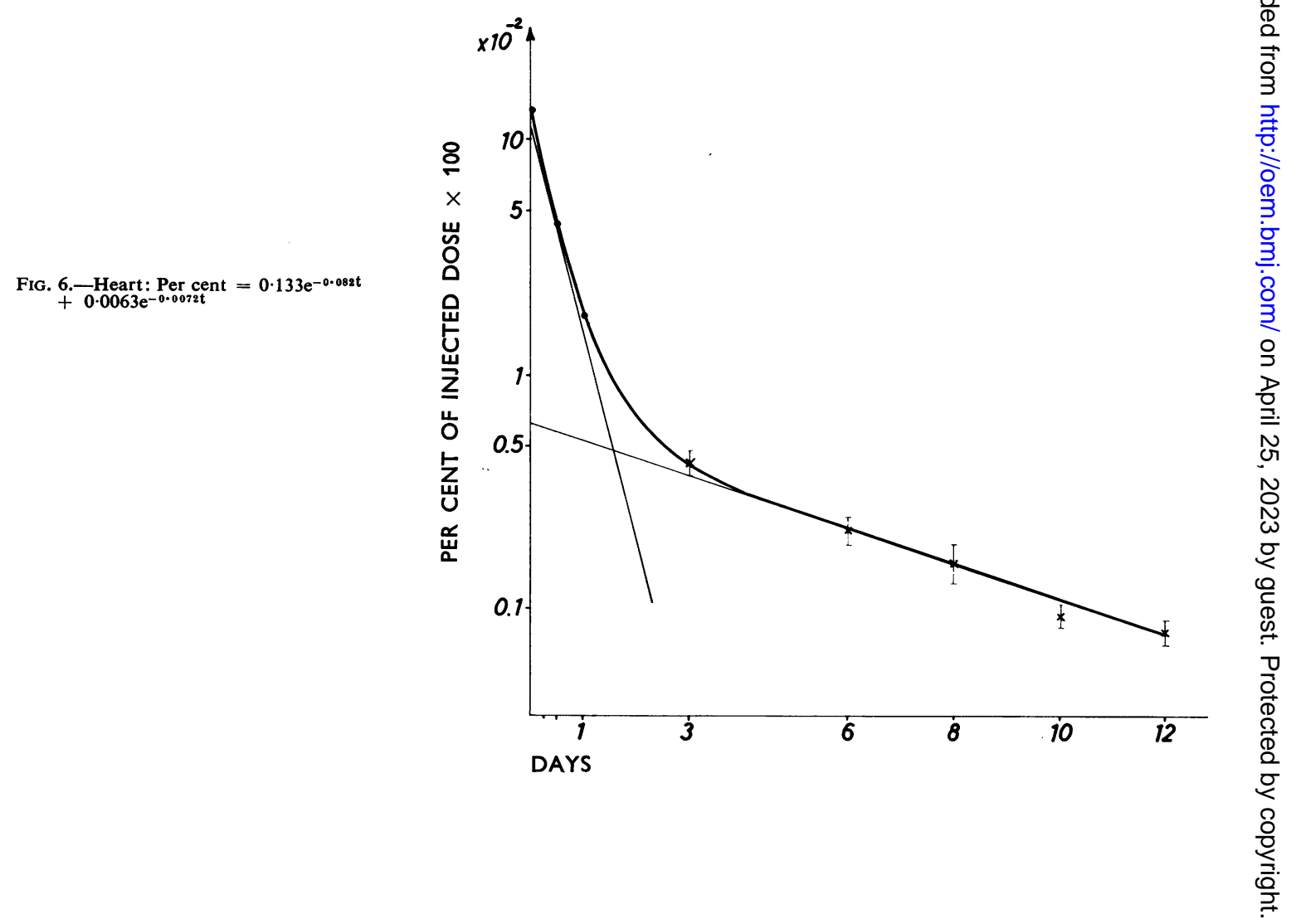




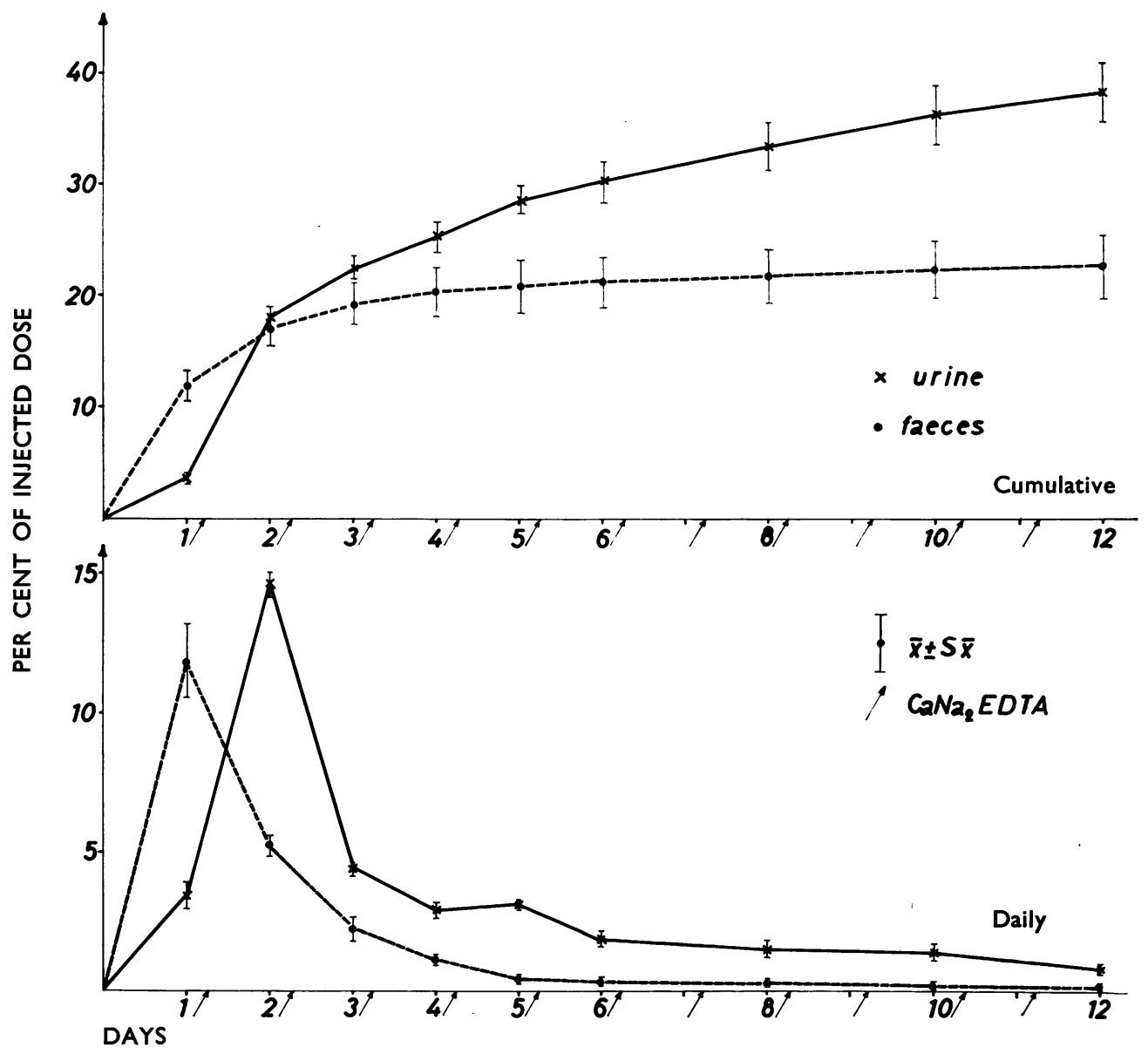

Fig. 7.-Excretion of ${ }^{210} \mathrm{~Pb}$ in faeces and in urine.

TABLE 1

${ }^{21} \mathrm{~Pb} / \mathrm{g}$. FRESH TISSUE AS PERCENTAGE OF THE INJECTED DOSE (100 $\left.\mu \mathrm{g} . / \mathrm{RAT}\right)$

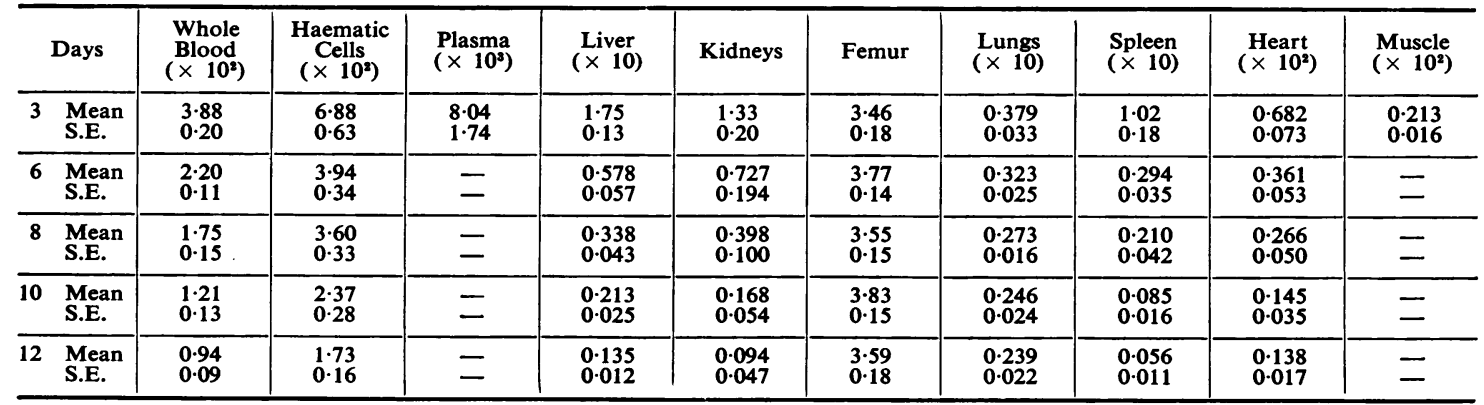

S.E. = standard deviation of the mean. 
TABLE 2

PERCENTAGES OF INTRAVENOUSLY INJECTED ${ }^{210} \mathrm{~Pb}(100 \mu \mathrm{g} . / \mathrm{RAT})$ FOUND IN VARIOUS TISSUES AFTER 23 DAYS

\begin{tabular}{|c|c|c|c|c|c|c|c|c|c|c|}
\hline & & $\begin{array}{l}\text { Whole } \\
\text { Blood } \\
\left(\times 10^{2}\right)\end{array}$ & $\underset{\left(\times 10^{2}\right)}{\text { Haematic }}$ & $\begin{array}{r}\text { Plasma } \\
\left(\times 10^{2}\right)\end{array}$ & $\underset{\left(\times 10^{2}\right)}{\text { Liver }}$ & $\begin{array}{c}\text { Kidneys } \\
(\times 10)\end{array}$ & Femur & $\begin{array}{c}\text { Lungs } \\
(\times 10)\end{array}$ & $\begin{array}{l}\text { Spleen } \\
(\times 10)\end{array}$ & $\underset{\left(\times 10^{2}\right)}{\text { Heart }}$ \\
\hline $\mathrm{CaNa}_{2} \mathrm{EDTA}$ & $\begin{array}{l}\text { Mean } \\
\text { S.E. }\end{array}$ & $\begin{array}{r}11.0 \\
0.5\end{array}$ & $\begin{array}{l}5 \cdot 78 \\
0 \cdot 72\end{array}$ & $\begin{array}{l}4.46 \\
3.44\end{array}$ & $\begin{array}{l}4.94 \\
0.43\end{array}$ & $\begin{array}{l}0.18 \\
0.04\end{array}$ & $\begin{array}{l}1 \cdot 75 \\
0 \cdot 15\end{array}$ & $\begin{array}{l}0.40 \\
0.03\end{array}$ & $\begin{array}{l}0.12 \\
0.02\end{array}$ & $\begin{array}{l}0.11 \\
0.02\end{array}$ \\
\hline Controls & Mean & $17 \cdot 5$ & 16.00 & $0 \cdot 15$ & $7 \cdot 80$ & $0 \cdot 28$ & $1 \cdot 50$ & 0.50 & - & - \\
\hline
\end{tabular}

Treated rats received intravenous $\mathrm{CaNa}_{2}$ EDTA on days 8, 9, 10; 14, 15, 16; and 21, 22 and 23.

the lead which was readily mobilized was rapidly removed by EDTA, whereas the removal of the rest, probably corresponding to the more stable endogenous lead complexes, was only indirectly and slightly accelerated.

$\mathrm{CaNa}_{2}$ EDTA did not mobilize the lead from bone, in which the concentration of the metal remained unchanged during the whole period of treatment.

The excretion of lead after the administration of $\mathrm{CaNa}_{2}$ EDTA is shown in Figure 7. Compared with the controls (Castellino and Aloj, 1964), $\mathrm{CaNa}_{2}$ EDTA significantly increased the excretion of lead in the urine but decreased excretion in the faeces. The greatest effect was observed after the first administration of the chelant, and urinary lead reached its maximum at 48 hours. Over the whole 12-day period of treatment, $38 \%$ of the dose (fiducial limits $31.7 \%$ to $44.7 \%$ ) was excreted by urine and $23 \%$ (fiducial limits $15.6 \%$ to $29.8 \%$ ) was excreted by faeces. The total excretion, $61 \%$, was not significantly higher than from the controls.

Treatment with CaNa ${ }_{2}$ EDTA Starting Seven Days after Lead Injection.- In Table 2 the ${ }^{210} \mathrm{~Pb}$ in various tissues of treated rats is compared with the ${ }^{210} \mathrm{~Pb}$ in the same tissues of controls 23 days after the injection of ${ }^{210} \mathrm{~Pb}$. The concentrations in the controls were calculated by extrapolating the curves in the preceding paper. $\mathrm{CaNa}_{2}$ EDTA removed some lead from all tissues except bone. Table 3 shows that $\mathrm{CaNa}_{2}$ EDTA slightly increased the urinary elimination of lead without modifying that in the faeces. Thus administration of EDTA when the slow removal phase of lead was predominant resulted in negligible mobilization of lead.

Oral Administration of Lead Acetate and CaNa ${ }_{2}$ EDTA.-Tables 4 and 5 show the results obtained in two groups of rats, one of which had been treated with $\mathrm{CaNa}_{2}$ EDTA.

In both groups, the percentages of ${ }^{210} \mathrm{~Pb}$ absorbed through the intestine, excreted by faeces, and found in the gastro-intestinal tract were similar. In contrast, rats treated with $\mathrm{CaNa}_{2}$ EDTA contained less ${ }^{210} \mathrm{~Pb}$ fixed in soft tissues and in bone $(\mathrm{P}<0.01)$ and
TABLE 3

URINARY AND FAECAL EXCRETION OF ${ }^{210} \mathrm{~Pb}$ (percentage of injected dose of $100 \mu \mathrm{g}$.)

\begin{tabular}{|c|c|c|c|c|}
\hline \multirow{2}{*}{$\begin{array}{c}\text { Time } \\
\text { (days) }\end{array}$} & \multicolumn{2}{|c|}{ Urine } & \multicolumn{2}{|c|}{ Faeces } \\
\hline & Daily & Cumulative & Daily & Cumulative \\
\hline $\begin{array}{l}1 \\
2 \\
3 \\
4 \\
5 \\
6 \\
7 \\
8^{*} \\
9^{*} \\
10^{*} \\
11 \\
12 \\
13 \\
14^{*} \\
15^{*} \\
16^{*} \\
17^{*} \\
18^{\circ} \\
19 \\
20 \\
21^{*} \\
22^{*} \\
23^{*}\end{array}$ & $\begin{array}{l}2 \cdot 45 \pm 0.48 \\
2 \cdot 43 \\
0 \cdot 89 \\
1 \cdot 00 \\
0 \cdot 38 \\
0 \cdot 35 \\
0 \cdot 31 \\
2 \cdot 19 \pm 0.40 \\
1 \cdot 50 \\
1 \cdot 42 \\
0 \cdot 26 \\
0 \cdot 19 \\
0 \cdot 34 \\
0 \cdot 85 \pm 0 \cdot 13 \\
1 \cdot 14 \\
0 \cdot 98 \\
0 \cdot 22 \\
0 \cdot 07 \\
0 \cdot 11 \\
0 \cdot 09 \\
0.68 \pm 0.08 \\
0 \cdot 45 \\
0.41\end{array}$ & $\begin{array}{l}2 \cdot 45 \pm 0 \cdot 48 \\
4 \cdot 88 \\
5 \cdot 77 \\
6 \cdot 77 \\
7 \cdot 15 \\
7 \cdot 50 \\
7 \cdot 81 \\
10 \cdot 00 \pm 2 \cdot 05 \\
11 \cdot 50 \\
12 \cdot 92 \\
13 \cdot 18 \\
13 \cdot 37 \\
13 \cdot 71 \\
14 \cdot 56 \pm 1 \cdot 30 \\
15 \cdot 70 \\
16 \cdot 68 \\
16 \cdot 90 \\
16 \cdot 97 \\
17 \cdot 08 \\
17 \cdot 17 \\
17 \cdot 85 \pm 1 \cdot 24 \\
18 \cdot 30 \\
18 \cdot 71\end{array}$ & $\begin{array}{l}8.41 \pm 2 \cdot 16 \\
13 \cdot 18 \\
3.86 \\
1.67 \\
0.90 \\
0.67 \\
0.82 \\
0.54 \pm 0.03 \\
0.54 \\
0.29 \\
0.22 \\
0.16 \\
0.25 \\
0.16 \pm 0.05 \\
0.17 \\
0.17 \\
0.17 \\
0.11 \\
0.15 \\
0.11 \\
0.12 \pm 0.02 \\
0.08 \\
0.06\end{array}$ & $\begin{array}{l}8 \cdot 41 \pm 2 \cdot 16 \\
21 \cdot 59 \\
25 \cdot 45 \\
27 \cdot 12 \\
28 \cdot 02 \\
28 \cdot 69 \\
29 \cdot 51 \\
30 \cdot 04 \pm 3 \cdot 35 \\
30 \cdot 58 \\
30 \cdot 87 \\
31 \cdot 09 \\
31 \cdot 25 \\
31 \cdot 50 \\
31 \cdot 66 \pm 3 \cdot 40 \\
31 \cdot 83 \\
32 \cdot 00 \\
32 \cdot 17 \\
32 \cdot 28 \\
32 \cdot 43 \\
32 \cdot 54 \\
32 \cdot 66 \pm 3 \cdot 00 \\
32 \cdot 74 \\
32 \cdot 80\end{array}$ \\
\hline
\end{tabular}

Means and standard errors are shown.

*Injection of $\mathrm{CaNa}_{2}$ EDTA.

excreted more lead in the urine $(P<0.01)$. For soft tissues, $\mathrm{CaNa}_{2} \mathrm{EDTA}$ did not have a significant effect on any one tissue $(P>0.05)$, but in every tissue the mean concentration was lowered, so that the overall effect is significant.

Thus, when treatment with $\mathrm{CaNa}_{2}$ EDTA started before the injection of ${ }^{210} \mathrm{~Pb}$, the chelant bound the metal ions as soon as they passed into the body

TABLE 4

${ }^{210} \mathrm{~Pb}$ FOUND IN URINE, FAECES, AND GASTROINTESTINAL TRACT ONE' DAY AFTER $500 \mu \mathrm{g}$. LEAD GIVEN ORALLY (percentage of dose)

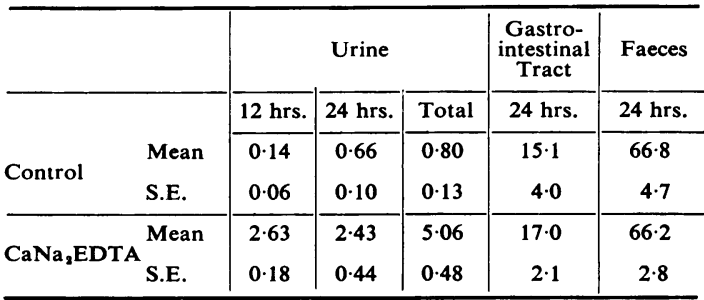


TABLE 5

${ }^{210} \mathrm{~Pb} / \mathrm{g}$. FRESH TISSUE ONE DAY AFTER $500 \mu \mathrm{g}$. LEAD GIVEN ORALLY (percentage of dose)

\begin{tabular}{|c|c|c|c|c|c|c|c|c|c|c|c|}
\hline & & $\underset{\left(\times 10^{3}\right)}{\text { Plasma }}$ & $\begin{array}{c}\text { Haematic } \\
\text { Cells } \\
(\times 10)\end{array}$ & $\begin{array}{l}\text { Whole } \\
\text { Blood } \\
(\times 10)\end{array}$ & Liver & Kidneys & $\begin{array}{l}\text { Spleen } \\
(\times 10)\end{array}$ & $\underset{(\times 10)}{\text { Lungs }}$ & Femur & $\underset{\left(\times 10^{2}\right)}{\text { Heart }}$ & $\begin{array}{c}\text { Striated } \\
\text { Muscle } \\
\left(\times 10^{2}\right)\end{array}$ \\
\hline Control & $\begin{array}{l}\text { Mean } \\
\text { S.E. }\end{array}$ & $\begin{array}{l}0.444 \\
0.050\end{array}$ & $\begin{array}{l}0.622 \\
0.153\end{array}$ & $\begin{array}{l}0.308 \\
0.054\end{array}$ & $\begin{array}{l}0 \cdot 132 \\
0.034\end{array}$ & $\begin{array}{l}0 \cdot 894 \\
0 \cdot 190\end{array}$ & $\begin{array}{l}0 \cdot 604 \\
0 \cdot 143\end{array}$ & $\begin{array}{l}0.202 \\
0.048\end{array}$ & $\begin{array}{l}0.379 \\
0.046\end{array}$ & $\begin{array}{l}0.456 \\
0.124\end{array}$ & $\begin{array}{l}0.182 \\
0.066\end{array}$ \\
\hline $\mathrm{CaNa}_{2}$ EDTA & $\begin{array}{l}\text { Mean } \\
\text { S.E. }\end{array}$ & $\begin{array}{r}0.532 \\
0.014 \\
P>0.05\end{array}$ & $\begin{array}{r}0.425 \\
0.076 \\
P>0.05\end{array}$ & $\begin{array}{r}0.221 \\
0.046 \\
P>0.05\end{array}$ & $\begin{array}{r}0.056 \\
0.009 \\
P>0.05\end{array}$ & $\begin{array}{r}0.449 \\
0.067 \\
P>0.05\end{array}$ & $\begin{array}{r}0.250 \\
0.050 \\
P>0.05\end{array}$ & $\begin{array}{r}0.098 \\
0.011 \\
P>0.05\end{array}$ & $\begin{array}{r}0.118 \\
0.020 \\
P<0.01\end{array}$ & $\begin{array}{r}0.170 \\
0.028 \\
P>0.05\end{array}$ & $\begin{array}{r}0.054 \\
0.004 \\
P>0.05\end{array}$ \\
\hline
\end{tabular}

fluids and before they could be fixed in the bone. These experiments indicated that lead absorbed through the intestine was not concentrated in the liver but was distributed throughout the whole organism; and that treatment with $\mathrm{CaNa}_{2}$ EDTA by mouth did not modify the intestinal absorption of lead but increased its elimination in urine.

\section{Discussion}

The results showed that $\mathrm{CaNa}_{2}$ EDTA mobilized lead from all tissues with the exception of the bone. Lead, chelated in the EDTA molecule, passed into the plasma and was rapidly excreted by the kidney.

As the Pb-EDTA complex is excreted by the same route as EDTA itself, some lead ions, bound in the liver and in other parts of the body, were no longer excreted via the bile in faeces but were eliminated instead in the urine. This was shown by the increase in urinary excretion accompanied by a decrease in faecal excretion.

The kinetics of ${ }^{210} \mathrm{~Pb}$ removal from the different tissues explain the action of $\mathrm{CaNa}_{2}$ EDTA and confirm the complexity of lead metabolism. Since the disappearance of ${ }^{210} \mathrm{~Pb}$ in rats given EDTA still required two exponential terms for its expression, it seems that $\mathrm{CaNa}_{2}$ EDTA accelerated the removal of lead without modifying its metabolism. Weakly bound or extracellular lead was rapidly removed, but lead strongly complexed inside the cells was still removed only very slowly. It seems unlikely that such acceleration as there was of this slow phase was brought about by any direct action of the chelant on lead in the cells. It is more likely that, by removing some of the extracellular lead, it increased the rate of transport out of the cells by increasing the concentration gradient. This hypothesis is confirmed by the results obtained in the rats treated with $\mathrm{CaNa}_{2}-$ EDTA some days after lead injection, when the rapid phases of ${ }^{210} \mathrm{~Pb}$ disappearance were over. In these animals $\mathrm{CaNa}_{2}$ EDTA had only a slight effect on the excretion of lead and on the percentages of metal fixed in the tissues. We therefore agree with Teisinger et al. $(1958 \mathrm{a}, \mathrm{b})$ that $\mathrm{CaNa}_{2}$ EDTA passes into the extravascular space where it binds lead ions, but does not penetrate the cells.

$\mathrm{CaNa}_{2}$ EDTA did not mobilize lead from bone, in which probably the metal, bound to other ions, is fixed as a stable organic compound. Previous researches showed that there are analogies between calcium and lead metabolism in the bone (Nishimura, 1957), and that lead is fixed by the osteons (Vincent, 1957). Discordant views, however, have been expressed on the possibilities of modifying the fixation of lead in bone. Some authors (Hunter and Aub, 1927; Nishimura, 1957) think that parathyroid hormones modify the fixation of lead in bone, wheras Calhoun, McLean, Hudson, and Aub (1954) found that neither a low nor a high calcium diet, nor parathyroid hormones, affected lead excretion. This problem needs further study. Our experiments showed that $\mathrm{CaNa}_{2}$ EDTA lowered lead deposition only when the chelant was given before lead and are in agreement with previous work on the mobilization of radioactive metals with chelating agents by Foreman, Fuqua, and Norwood (1954) and by Catsch (1961) and Catsch and Schindewolf-Jordan (1961).

Finally, it has been supposed that the oral use of EDTA could increase the intestinal absorption of lead. The increase in urinary lead excretion would then depend on its higher absorption by the intestine and its more rapid removal out of the tissues. Our experiments show that the oral administration of $\mathrm{CaNa}_{2}$ EDTA caused a great increase of urinary lead excretion without modifying its intestinal absorption: about $18 \%$ of the lead was absorbed by rats whether they were treated with EDTA or not.

\section{REFERENCES}

Albahary, C., Truhaut, R., Boudène, C., and Desoille, H. (1961). Presse méd., 69, 2121 .

Bastenier, H., Deslypere, P., and de Graef-Millet (1958). Proc. 12th Internat. Congr. Occup. Hlth, Helsinki. 1957, Vol. III, p. 243.
Bell, R. F., Gilliland, J. C., Boland, J. R., and Sullivan, B. R. (1956). Arch. industr. Hith, 13, 366.

Calhoun, J. A., McLean, R., Hudson, J. C., and Aub, J. C. (1954). Arch. industr. Hyg., 9,'9.

Castellino, N., and Aloj, S. (1964). Brit. J. industr. Med., 21, 308. - , and Grieco, B. (1964). Folia med. (Napoli), 47, 57.

Catsch, A. (1961). Fed. Proc., 20, Suppl. 10, p. 206

, and Schindewolf-Jordan, D. (1961). Nature, 191, 715. 
Srbová, J., and Teisinger, J. (1957). Arch. Gewerbepath. Gewerbehyg. $15,572$.

Desoille, H., Albahary, C., Truhaut, R., and Boudène, C. (1958) Proc. 12th I III Foreman, H., Fuqua, P. A., and Norwood, W. D. (1954). Arch.
industr. Hyg., 10, 226.

-, and Trujillo, T. T. (1954). J. Lab. clin. Med., 43, 566.

-, Vier, M., and Magee, M. (1953). J. biol. Chem., 203, 1045.

Hunter, D., and Aub, J. C. (1927). Quart.J. Med., 20, 123.

Kehoe, R. A. (1955). J. Amer. med. Ass., 157, 341.

Teisinger, J., Lustinec, K., and Srbová, J. (1958a). Arch. industr. Hith, 17, 302 .

- and Srbová, J. (1956). Arch. Gewerbepath. Gewerbehyg., 14, 579.

(1959). Brit. J. industr. Med. 16, 148.

Zumanová, R., and Zezula, I. (1958b). Arch. industr. Hlth, Vincent, J. (1957). Rev. belge Path., 26, 161

Williams, J. D. Matthews, G. A., and Judd, A. W. (1962). Brit. J. Williams, J. D., Matthews,

Petrović, L. J., Stanković, M., Savićević, M., and Poleti, D. (1960). Brit. J. industr. Med., 17, 201.

Zambrano, A., and Rossi, L. (1955). Rif. med., 64, 387. 